\title{
Service Quality in Early Intervention Centres: An Analysis of Its Influence on Satisfaction and Family Quality of Life
}

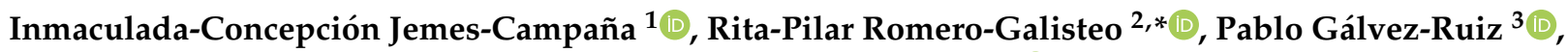 \\ Maria-Teresa Labajos-Manzanares ${ }^{2}$ and Noelia Moreno-Morales ${ }^{2}$ (D) \\ 1 Doctoral School, University of Málaga, 29071 Málaga, Spain; ijemes@uma.es \\ 2 Department of Fhysiotherapy, University of Málaga, C/Arquitecto Francisco Peñalosa, s/n., \\ 29071 Málaga, Spain; mtlabajos@uma.es (M.-T.L.-M.); nmm@uma.es (N.M.-M.) \\ 3 Faculty of Law and Social Sciences, Valencian International University, 46002 Valencia, Spain; \\ pgalvez@universidadviu.com \\ * Correspondence: rpromero@uma.es; Tel.: +34-95-195-2862
}

check for

updates

Citation: Jemes-Campaña, I.-C.; Romero-Galisteo, R.-P.; Gálvez-Ruiz,

P.; Labajos-Manzanares, M.-T.;

Moreno-Morales, N. Service Quality in Early Intervention Centres: An Analysis of Its Influence on Satisfaction and Family Quality of Life. Children 2021, 8, 716. https:// doi.org/10.3390/children8080716

Academic Editor: Marco Carotenuto

Received: 19 July 2021

Accepted: 20 August 2021

Published: 21 August 2021

Publisher's Note: MDPI stays neutral with regard to jurisdictional claims in published maps and institutional affiliations.

Copyright: (c) 2021 by the authors. Licensee MDPI, Basel, Switzerland. This article is an open access article distributed under the terms and conditions of the Creative Commons Attribution (CC BY) license (https:// creativecommons.org/licenses/by/ $4.0 /)$.

\begin{abstract}
Early Intervention (EI) is a set of interventions focused on responding to the needs of children with or at risk of developmental problems. This study aimed to investigate the relationships between the perceived quality of service, satisfaction and family quality of life. Methods: to conduct a multi-centre, transversal study with a non-probabilistic sample. The participants $(\mathrm{N}=1551)$ were families from 24 Early Intervention Centres (EICs) located in Spain. Results: The results indicated an adequate fit of the measurement and structural models, with the latter showing a capacity of $73 \%$ to predict the family quality of life. The structural model established that the perceived service quality was a positive and significant predictor of satisfaction $(\beta=0.85 ; p<0.001)$. Both the perceived quality of service $(\beta=0.28 ; p<0.001)$ and satisfaction $(\beta=0.33 ; p<0.001)$ obtained a similar positive and significant relationship with family quality of life, which was slightly stronger than satisfaction. Conclusions: This study provided a better understanding of the importance of the services offered in EICs and their influence on the satisfaction and family quality of life of their users. Thus, delving into these relationships was highly relevant for decision-making in the context of EI.
\end{abstract}

Keywords: Early Intervention Centres; perceived quality of service; family quality of life; satisfaction

\section{Introduction}

Early Intervention (EI) is a set of interventions focused on responding to the transient or permanent needs of children between 0 and 6 years of age with or at risk of suffering with developmental disorders [1].

The main objective of EI is to favour the development and wellbeing of a child and his/her family, facilitating his/her integration in the environment, as well as his/her personal autonomy [1]. EI centres work on the cognitive area; language and communication, personal autonomy and motor skills; and also provide counselling and individual and/or group intervention with families [2].

Although EI programmes have traditionally disregarded environmental and family contexts [3], this approach has changed in the last decades towards a model that values the family scope to a greater extent [4]. The growing interest in the family and a child's environment is due to their relevance in the evaluation and rehabilitation of children with special needs, as they play an essential role throughout the entire process [5]. Moreover, different studies support the participation and the empowerment of the family and a rich environment to promote advancements in the development of children with developmental disorders [6-10].

On the other hand, EICs, as organisations related to services, must focus their management strategies on the client and his/her needs. Ensuring these objectives is necessary to facilitate the early access to EICs and to streamline the acceptance process to these 
services [11]. In this sense, it is essential to provide good service, and the evaluation of such service is a basic step in the development of high-quality improvement programmes.

Access to EI services in Spain varies depending on the autonomous community in which it is provided [12]. Although developmental alterations or their risks can be detected in healthcare services, and in school or family environments, referral to the EI service can be completed through specialised Social Services, Education Services or, as is the case in Andalusia, through EI units of the Health Service [13].

Regarding human resources, the professional profiles of the EI resources depend on the autonomous community and the means of funding, with psychologists, speech therapists and physiotherapists being the most common, followed by special education teachers, occupational therapists and other child development professionals [14].

In the case of EI, the perspective of the parents about the quality of the service received can facilitate changes in such services, thus maximising the opportunities for psychomotor development in children with developmental disorders. Given the importance of this aspect, it is relevant to know and understand the beliefs of the families regarding the quality of the EI services, as well as the expectations, engagement and perspectives of the families [15-17]. Due to the multidimensionality of the construct, as well as the lack of reliability and operationalisation, several authors highlight the need to adapt the dimensions of such a model to the context and service to be evaluated [18], since, depending on the type of business, the dimensions of service quality can be considerably different.

In the evaluation of social services, Moliner-Cantos et al. [19] state that service quality contributes to improving the conditions of social services and favours the quality of life of its users, an approach that has drawn the attention of different studies in the context of EI [20]. Moreover, the study of the quality of life could serve as a guide in a holistic approach to the evaluation and intervention of EIC and help to plan interventions for both children and their parents/guardians [21]. Aside from the quality of life of the child, the quality of life of the family can also shed light on the efficacy and quality of the EI programme that they receive [22].

In fact, in the last decade, family quality of life has become a decisive element for the evaluation of services provided in EI, since identifying the variables that improve quality of life can determine the appropriate treatment [23]. Several studies demonstrate the relationship between both constructs, with service quality being a predictor of the quality of life [24].

Concerning satisfaction, this construct has gained an increased interest in the scientific literature for being considered as preceding loyalty [25], which is a fundamental objective in service organisations. Specifically in EI, some studies have evaluated the levels of satisfaction [26] and the quality of life [27] of families who use these services, although they do not delve into the relationship between the two constructs. In the hospital context, better levels of quality of life are detected in hospitalised patients when their satisfaction with the service is high [28]. The study by Lanfredi et al. [29] in a mental health population reported similar results, asserting that satisfaction is a precursor to quality of life.

Satisfaction and service quality have also shown a direct and positive correlation in different studies. Such investigations state that service quality precedes user satisfaction [30] and, despite the lack of thorough research on this relationship in the EI context, such a correlation has been investigated in other contexts, such as sports [31] and transportation [32].

Therefore, the aim of this study was to determine the influence of perceived service quality on family quality of life $\left(\mathrm{H}_{1}\right)$ and satisfaction $\left(\mathrm{H}_{2}\right)$, as well as the influence of satisfaction on family quality of life $\left(\mathrm{H}_{3}\right)$ (Figure 1$)$ : 


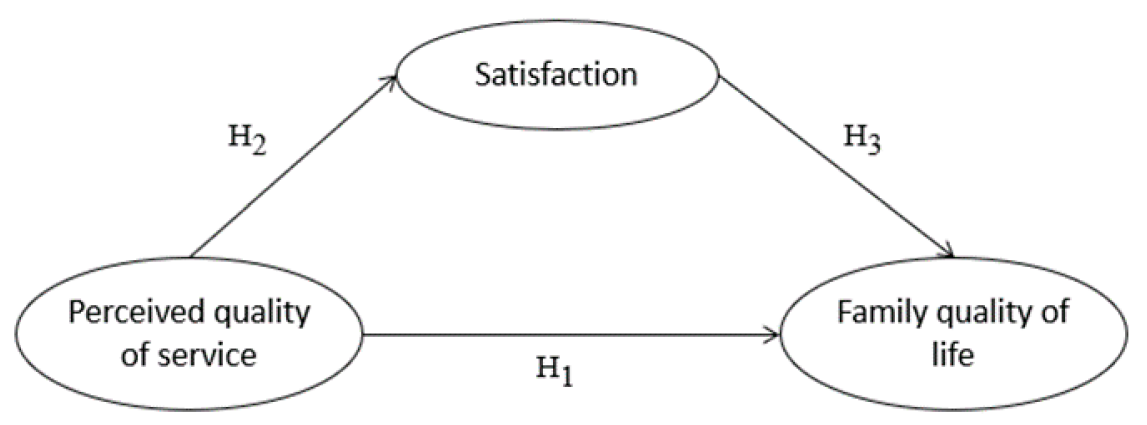

Figure 1. Proposed conceptual model.

\section{Materials and Methods}

\subsection{Participants}

This was a quantitative study with a non-probabilistic sample of 1551 parents (1235 women and 308 men) from 24 EIC located in the region of Andalusia (Southern Spain). Early intervention services in Spain were organised differently in each of the autonomous communities into which the country is divided, and each of these had the authority to organise the services that it provided in a different way [33]. In the specific case of Andalusia, it was legislated according to Decree 85/2016, of 26 April [13], which regulates the integral intervention of Early Childhood Care. The participants were recruited during the period from October to November 2018. The inclusion criteria were: (1) family members and/or caregivers of children with or at risk of presenting developmental disorders/developmental delays who attended EI centres; (2) family members and/or caregivers with literacy skills in Spanish to understand the questionnaire; and (3) family members and/or caregivers who provided a duly completed informed consent form. Participants were not excluded on the basis of the type of injury their child suffered or previous hospital care received.

At the beginning of the study, the managers of the different EI centres were contacted via e-mail. The questionnaires were sent to these centres via ordinary mail and identified with a numerical code. Authorisation was requested from the different centres through a letter explaining the purpose of the investigation and the procedure to be carried out. The participations received verbal and written information on the objectives and methodology of the study, and they freely agreed to collaborate by signing an informed consent form. In accordance with the Declaration of Helsinki, the anonymity and confidentiality of their responses was assured. The questionnaires took around $15 \mathrm{~min}$ to complete and were completed in the waiting rooms of the EIC; the participants were asked for maximum sincerity and honesty.

Permission to undertake this study was granted by the Research Ethics Committee of the University of Málaga (code 22-2018-H). Table 1 summarises the background characteristics of the sample.

\subsection{Measures}

The participants answered three questionnaire items. To measure the perceived quality of EICs, the Inventory of Quality in Early Intervention Centres (IQEIC) [34] was used, composed of four dimensions: centre facilities (CF), treatment room and material (TRM), qualified staff (QS), and technical or specific information (TSI). This tool was used in previous studies, obtaining adequate psychometric properties in the adjustment of the model $\left(\chi^{2} / \mathrm{df}=2.53 ; \mathrm{CFI}=0.94 ; \mathrm{TLI}=0.92 ; \mathrm{IFI}=0.94 ; \mathrm{RMSEA}=0.059\right)$. The response format for all items was a 5-point Likert scale rated from 1 (strongly disagree) to 5 (strongly agree). To measure the family quality of life, the CdVF-ER for families with children under the age of 18 years [35] was used, divided into five dimensions: Family Resources (FR), Family adaptation (FA), Family Climate (FC), Emotional Stability (ES), and Economic Well-Being (EW-B). The instrument was answered with a 5-point Likert scale with the 
following answer choices: never, rarely, sometimes, often, and always. Furthermore, the option, not applicable, was also present for the families to select if the item did not reflect their situation. Finally, a satisfaction scale composed of three items was used [36], which had already been employed in this context [37] obtaining an adequate internal consistency $(\alpha=0.90)$, with the same response format as the IQEIC instrument. Appendix A shows the items used for each scale.

Table 1. Sociodemographic characteristics of the participants.

\begin{tabular}{cccc}
\hline Characteristics & $n$ & \% & Missing (\%) \\
\hline Gender & 308 & 19.8 & $8(0.6)$ \\
Male & 1235 & 79.6 & \\
Female & & & $129(8.5)$ \\
Age (years) & 201 & 12.9 & \\
$20-30$ & 847 & 54.9 & \\
$31-40$ & 338 & 21.7 & \\
$41-50$ & 36 & 2.3 & \\
$>51$ & & & \\
Academic achievement & 74 & 4.8 & \\
Elementary education & 311 & 20.1 & \\
Middle school completion & 562 & 36.2 & \\
High school education & 433 & 27.9 & \\
College education & 52 & 3.4 & \\
Master or doctorate graduates & & & \\
Length of stay (in months) & 643 & 41.4 & \\
$0-12$ & 459 & 29.5 & \\
13-24 & 200 & 12.8 & \\
25-36 & 96 & 6.1 & \\
$>37$ & &
\end{tabular}

\subsection{Statistical Procedures}

Descriptive statistics were calculated for the participants' characteristics $(n[\%])$. All the data were analysed using SPSS Statistics and AMOS Graphics statistical software (version 21.0). An exploratory factor analysis (EFA) was conducted using principal component analysis and oblimin oblique rotation. The choice of this experimental route was based on the fact that this study employed a measurement model composed of three constructs that had not been previously validated. Assumptions needed for factor analysis were verified and, subsequently, the factorability of the items was examined via Bartlett's sphericity test and the Kaiser-Meyer-Olkin (KMO) measure of sampling adequacy. To analyse the internal consistency, Cronbach's alpha and the corrected homogeneity index (CHI) were calculated. In order to test the model we used the classical two-step assessment proposed by different authors [38,39] using a maximum likelihood method of estimation recommended by Jöreskog and Sörbom [40]: (1) a confirmatory factor analysis (CFA) was conducted to verify the EFA structure and assess the measurement model, and (2) a structural equation model (SEM) analysed the predicted hypothesised relationships between the three reflective variables: perceived service quality, family quality of life, and satisfaction. Convergent validity and reliability were determined by assessing the composite reliability (CR) and the average variance extracted (AVE). According to Hair et al. [41], CR values over 0.70 and AVE scores over 0.50 were considered as good scores; however, AVE values slightly below 0.50 were also acceptable as long as the CR measured more than 0.60 [42].

Before the main analysis, evidence of potential multicollinearity between predictors was verified using bivariate comparisons. Looking at the correlations among the predictors, we found that the highest correlation was found between the service quality and satisfaction (0.78) without multicollinearity problems, according to the established values $(r=0.90)$ [43] We also examined the variance inflation factor (VIF) for our final model, obtaining a maximum value of 1.86 , lower than the established values in which multicollinearity was considered problematic for the estimates [44] 
The following goodness-of-fit indexes were used in both analyses to test the adequacy of the models: the ratio of chi-square to its degrees of freedom $\left(\chi^{2} / \mathrm{df}\right)$, the Comparative Fit Index (CFI), the Tucker-Lewis Index (TLI), the Incremental Fit Index (IFI), the Parsimony Comparative Fit Index (PCFI), and the Root Mean Square Error of Approximation (RMSEA). For these indexes, the following cut-off values were adopted: $\chi^{2} / \mathrm{df} \leq 5$ [45], CFI, TLI and IFI $\geq 0.90$ [46], PCFI $\geq 0.80$ [47] and RMSEA $\leq 0.08[48,49]$.

\section{Results}

\subsection{Exploratory Factor Analysis and Reliability}

In terms of structural validity, the analysis of the measurement model yielded a KMO measure of 0.94 with a significant Bartlett's test $(p<0.001)$. The inspection of eigenvalues produced a structure accounting for $56.63 \%$ of the variance. The items with communalities above $50 \%$ and items with factor loadings over the minimum acceptable value $(0.50)$ were accepted [41]. Thus, the IQEIC maintained the original item structure, but the results of the CdVF-ER suggested a different dimensionality, with a factor structure of 21 items. With respect to reliability, high alpha coefficients $(\alpha=0.70)$ [50] demonstrated a good internal consistency for the different factors of IQEIC $(\mathrm{CF}=0.72$; TRM $=0.88 ; \mathrm{QS}=0.94 ; \mathrm{TSI}=0.89)$, CdVF-ER (FC = 0.75; ES = 0.77; EW-B = 0.74; FA = 0.77; FR = 0.71) and satisfaction (0.93).

\subsection{Confirmatory Factor Analysis}

The measurement model of the 10-factor structure was examined, yielded the corresponding value of: $\chi^{2}(\mathrm{df}=1130)=5456.81 ; \chi^{2} / \mathrm{df}=4.82 ; \mathrm{CFI}=0.90 ; \mathrm{TLI}=0.89 ; \mathrm{IFI}=0.90$; PCFI $=0.83$; and RMSEA $=0.050$. An examination of the factor loading $(\lambda)$ and modification indices (MI) indicated the possible areas for improvement. In all cases, the observed variables showed a factor loading value of greater than the conservative threshold of 0.50 [41]. According to the MI, with the assumption that all the respective items involved presented some similar content, covariance was established as being between CF1 and CF2 (MI = 186.27), TRM1 and TRM2 (MI = 264.72), QS1 and QS2 (MI = 134.14), and TSI5 and TSI6 (MI = 225.89). Following the inclusion of the four covariance, there was an improvement in the indices of fit: $\chi^{2}(\mathrm{df}=1122)=3896.07 ; \chi^{2} / \mathrm{df}=3.47 ; \mathrm{CFI}=0.93 ; \mathrm{TLI}=0.93$; $\mathrm{IFI}=0.94 ; \mathrm{PCFI}=0.85$; and RMSEA $=0.40$. All indices were satisfactory, including the value of $\chi^{2} / \mathrm{df}$, despite its high sensitivity to the sample size [41]. Construct reliabilities were greater than 0.60, average variance extracted (AVE) values were adequate [42] assuming the convergent validity, and squared interconstruct correlations were smaller than the respective AVE values [42] accepting the discriminant validity (Table 2).

Table 2. Cronbach Alpha $(\alpha)$, composite reliability (CR), average variance extracted (AVE) and discriminant validity.

\begin{tabular}{|c|c|c|c|c|c|c|c|c|c|c|c|c|c|}
\hline Factors & $\alpha$ & $\mathrm{CR}$ & AVE & FC & ES & EW-B & FA & FR & $\mathrm{CF}$ & TRM & QS & TSI & SAT \\
\hline $\mathrm{FC}$ & 0.75 & 0.84 & 0.47 & 1.0 & & & & & & & & & \\
\hline ES & 0.77 & 0.77 & 0.53 & 0.11 & 1.0 & & & & & & & & \\
\hline EW-B & 0.74 & 0.82 & 0.48 & 0.29 & 0.23 & 1.0 & & & & & & & \\
\hline FA & 0.77 & 0.81 & 0.52 & 0.07 & 0.31 & 0.12 & 1.0 & & & & & & \\
\hline FR & 0.71 & 0.75 & 0.50 & 0.03 & 0.28 & 0.04 & 0.16 & 1.0 & & & & & \\
\hline $\mathrm{CF}$ & 0.72 & 0.84 & 0.47 & 0.01 & 0.01 & 0.02 & 0.01 & 0.01 & 1.0 & & & & \\
\hline TRM & 0.88 & 0.89 & 0.58 & 0.09 & 0.01 & 0.02 & 0.01 & 0.01 & 0.71 & 1.0 & & & \\
\hline QS & 0.94 & 0.95 & 0.68 & 0.01 & 0.03 & 0.02 & 0.01 & 0.01 & 0.31 & 0.38 & 1.0 & & \\
\hline TSI & 0.89 & 0.89 & 0.58 & 0.01 & 0.06 & 0.03 & 0.02 & 0.01 & 0.40 & 0.44 & 0.49 & 1.0 & \\
\hline SAT & 0.93 & 0.93 & 0.82 & 0.01 & 0.01 & 0.03 & 0.02 & 0.34 & 0.37 & 0.62 & 0.62 & 0.72 & 1.0 \\
\hline
\end{tabular}

Note. FC = family climate; ES = emotional stability; EW-B = economic well-being; FA = family adaptation; FR = family resources; $\mathrm{CF}=$ centre facilities; $\mathrm{TRM}$ = treatment room and material; QS = qualified staff; TSI = technical or specific information; and SAT = satisfaction.

\subsection{Structural Equation Assessment}

Once the reliability and suitability of the measurement model were confirmed, the hypothetical model and the standardised regression loadings were subjected to a causal path analysis. The results indicated support for all the causal relationships, along with 
an adequate goodness-of-fit for the causal model: $\chi^{2}(\mathrm{df}=1064)=5251.84 ; \chi^{2} / \mathrm{df}=4.93$; $\mathrm{NFI}=0.91 ; \mathrm{CFI}=0.92 ; \mathrm{TLI}=0.90 ; \mathrm{IFI}=0.91 ;$ and $\mathrm{RMSEA}=0.50$. The hypothetical model established that the perceived service quality was positive and the significant predictors of satisfaction $(\beta=0.85 ; p<0.001)$, illustrating a predictive capacity of $73 \%$. Both perceived that service quality $(\beta=0.43 ; p<0.001)$ and satisfaction $(\beta=0.48 ; p<0.001)$ obtained a similar positive and significant relationship with family quality of life, which was slightly higher for satisfaction. However, the obtained results show that this was a partial mediation between the perceived service quality and family quality of life, governed by satisfaction (Table 3).

Table 3. Standardised regression weights for the causal paths.

\begin{tabular}{lccc}
\hline \multicolumn{1}{c}{ Relationships } & $\begin{array}{c}\text { Hypothesised } \\
\text { Relationship }\end{array}$ & $\begin{array}{c}\text { Standardised } \\
\text { Coefficient }\end{array}$ & Results \\
\hline $\begin{array}{l}\text { Perceived quality of service } \rightarrow \text { Quality of } \\
\text { family life }\end{array}$ & $\mathrm{H}_{1}$ & $0.28^{* * *}$ & Supported \\
$\begin{array}{l}\text { Perceived quality of service } \rightarrow \text { satisfaction } \\
\text { Satisfaction } \rightarrow \text { Quality of family life }\end{array}$ & $\mathrm{H}_{2}$ & $0.85^{* * *}$ & $\begin{array}{l}\text { Supported } \\
\mathrm{H}_{3}\end{array}$ \\
\hline Note. ${ }^{* * *} p$-value $<0.001$. & & &
\end{tabular}

\section{Discussion}

The aim of this research was to analyse the relationship between the perceived service quality, family quality of life and satisfaction in the context of EIC. The findings show that the perceived service quality can be used to predict the family quality of life in children who receive EI services, and that satisfaction is a variable that mediates family quality of life.

In general, EICs that provide services to children and their parents, are aware of the increasing interest in measuring the family quality of life, received support and perceptions of their users [51]. In this sense, different studies have delved into these constructs, although in an isolated manner, without relating the influence among them [21,52,53]. Nowadays, the field of EI is undergoing a significant conceptual change, and the old intervention model is being replaced with a social model in which the family and the environment are fundamental axes [1], thus the evaluation of aspects related to them is especially relevant.

There is evidence of the need to study family quality of life [54], perceived service quality [55] and satisfaction [56] in EI. In this sense, it is important to note that the use of valid and reliable measurement tools is a key component in both clinical practice and research. Therefore, the evaluation of the psychometric properties of the measurement instruments will help researchers and clinicians to choose the most suitable tool in order to better evaluate the construct they wish to assess [57], and, in this line, the present study contributes to the existing literature by proposing an evaluation model for users of EIC. The analyses conducted in this study show the same factor structure for the IQEIC, however, for the CdVF-ER the results show a scale with less items compared to Giné et al. [35]. The resulting measurement model consists of 50 items: 26 for service quality, 21 for family quality of life and 3 for satisfaction. For this model, the relevance criteria of the factor analysis are satisfactorily met, obtaining significance in the Bartlett test and KMO indices higher than 0.90 , with an explained variance extracted higher than $50 \%$. In addition, the internal consistency measured through Cronbach's alpha coefficient is adequate. Regarding the validity of the model, a satisfactory fit in the confirmatory factor analysis, and revealed good reliability evidence in terms of internal consistency and composite reliability. Furthermore, the validity of the model is demonstrated through the average variance extracted and the discriminant validity. Therefore, it is an optimal model for measuring the adequate psychometric properties that can be rapidly applied. In this regard, it is found that the factorial structure and the analysis of internal consistency give the instrument a validity and reliability that makes it suitable for use in the context of EI. 
With respect to the relationships model, all hypotheses are statistically significant and the model presents an acceptable fit to the data, thus confirming the three hypotheses. The results proved that the perceived service quality has a positive and significant influence on family quality of life, which supports $\mathrm{H}_{1}$, in line with Moliner-Cantos et al. [19] in the context of social services. It also shows a strong positive and significant influence on satisfaction, which supported $\mathrm{H}_{2}$, in agreement with studies conducted in other contexts, such as hospitality [58] and tourism [59]. Almasri et al. [60] analysed the relationship between service quality and family wellbeing in a cerebral palsy population, obtaining positive and significant relationships between these two constructs. Therefore, despite the fact that the direct focus is not family quality of life, it is shown that there is a growing interest in the study of the service provided and the family. An example of this is the work of Park and Kim [61], who analysed the relationship between the degree of motor deterioration of a child with developmental disorders and family stress and depression, or the study of Colver et al. [62], who explored the degree of disability and pain in the participation of the child with cerebral palsy in the home environment. Lastly, regarding satisfaction $\left(\mathrm{H}_{3}\right)$, it is observed that this variable has a positive and significant influence on family quality of life, which is in agreement with the results obtained by Lanfredi et al. [29] in a sample of schizophrenia patients.

One of the limitations of this study is the sample of participants, which is not representative of the EICs of Spain. However, the absence of common legislation in the entire Spanish territory favours the disparity of management models, which hinders the generalisation of the results of this investigation to other contexts. Another limitation is related to the questionnaire used to evaluate the perceived quality of the service, since it is designed to evaluate the EI service in the specialised centres by gathering information about tangible aspects, such as the facilities, treatment rooms and materials. Therefore, the reliability and validity that this tool has for EI centres is not guaranteed for those EI services provided only in natural environments, such as the family home.

Consequently, this study provides an evaluation model for family quality of life, highlighting the importance of perceived service quality and satisfaction through structural equation modeling. Despite the novelty of this type of analysis in EI, recent studies have used this methodology to evaluate how family quality of life is influenced by the quality of the relationship between the family and the reference professional $[63,64]$, and how the support received by the families from the professionals of EICs influences their quality of life [24]. Therefore, we consider that this study provides an interesting contribution to the specialised academic literature and paves the way for new research lines with the use of this methodology in the context of populations with functional diversity, such as the exploration into the influence of the degree of dependency of the child with developmental disorders on the perception of service quality, satisfaction and family quality of life.

Following the approach proposed by Ashcraft et al. [10], the current study contributes to a better understanding of the mechanisms by which parents can achieve empowerment and the expected outcomes in the field of pediatric rehabilitation in general, and EI in particular.

Regularly integrating assessments of perceived service quality in EI centres with instruments validated in this field/sector provides detailed information about the strengths and weaknesses of EI centres. In this way, managers/directors and professionals of EI centres can focus their efforts on maintaining factors that score higher and improving factors where scores are lower. This could lead to an increase in the quality of the service offered in EI centres.

\section{Conclusions}

The perceived quality and satisfaction with EICs can become important tools to achieve family quality of life, both in the children and families who receive EI services. This study delves into the relationships between these aspects, obtaining results of great relevance considering the lack of similar studies in the context of EI. Thus, the contributions 
of the present study allow providers of these services to respond to changing needs in a flexible manner, paving the way for future research.

Author Contributions: Conceptualisation, I.-C.J.-C. and R.-P.R.-G.; methodology, P.G.-R.; software, P.G.-R.; validation, I.-C.J.-C. and R.-P.R.-G.; formal analysis, P.G.-R.; investigation, I.-C.J.-C. and N.M.M.; resources, M.-T.L.-M. and N.M.-M.; data curation, P.G.-R.; writing-original draft preparation, M.-T.L.-M. and N.M.-M.; writing-review and editing, I.-C.J.-C., R.-P.R.-G., M.-T.L.-M., P.G.-R. and N.M.-M.; visualisation, R.-P.R.-G. and P.G.-R.; supervision, I.-C.J.-C. and N.M.-M. All authors have read and agreed to the published version of the manuscript.

Funding: This research received no external funding.

Institutional Review Board Statement: The study was conducted according to the guidelines of the Declaration of Helsinki, and approved by the Institutional Review Board (or Ethics Committee) of University of Málaga (protocol code 22-2018-H; 9 May 2018).

Informed Consent Statement: Informed consent was obtained from all subjects involved in the study.

Data Availability Statement: The data that support the findings of this study are available from the corresponding author, Rita Pilar Romero-Galisteo, upon reasonable request.

Acknowledgments: The authors thank the users' families from Early Intervention Centres for their willingness and collaboration with the study.

Conflicts of Interest: The authors declare no conflict of interest.

\section{Appendix A}

Table A1. Survey items.

Inventory of Quality in Early Intervention Centres (IQEIC) [37]

CF1 The centre is well located geographically

CF2 It is easy to reach the centre by public transport

CF3 The cleaning of the centre is adequate

CF4 The lighting of the centre is adequate

CF5 The waiting room is comfortable

CF6 The number of chairs in the waiting room is enough

Treatment rooms and material

TRM1 The number of treatment rooms is enough

TRM2 The treatment rooms are large enough

TRM3 The materials that are used in the centr are suitable

TRM4 The materials are in good condition for use

TRM5 The materials that are used in the treatment rooms are safe

TRM6 The work materials comply with the health and hygiene conditions

Qualified staff

QS1 The attention that users receive at the centre is suitable

QS2 Qualified staff have the necessary knowledge

QS3 Qualified staff are accessible

QS4 Qualified staff are available when users need them

QS5 Qualified staff have a close treatment

QS6 I value the contributions and initiatives of the qualified staff

QS7 Qualified staff are coordinated among themselves

QS8 Qualified staff know to adapt tasks to the user's needs

Technical or specific information

TSI1 The activities carried out with the user seem appropriate

TSI2 The activities proposed for users to work on at home are feasible

TSI3 The information received at the beginning of the treatment is consistent with the tasks subsequently performed

TSI4 I usually receive some programs to work with the user

TSI5 I usually receive some report about the progression of the user

TSI6 The information received about the user is clear 
Table A1. Cont.

\section{Inventory of Quality in Early Intervention Centres (IQEIC) [37]}

\begin{tabular}{|c|c|}
\hline & Quality of life (CdVF-ER) \\
\hline & Family Resources \\
\hline FR1 & My family adapts to the needs of the relative with developmental disorder \\
\hline FR2 & Our relatives and friend understand that the relative with developmental disorder can have a different behaviour \\
\hline FR3 & $\begin{array}{l}\text { My family organises considering the needs of the relative with developmental disorder } \\
\text { Family Adaptation }\end{array}$ \\
\hline FA1 & $\begin{array}{l}\text { My family respects the small decisions made by the relative with developmental disorder (choose clothes, organise } \\
\text { his/her space, etc.) }\end{array}$ \\
\hline FA2 & The relative with developmental disorder respects others when walking down the street \\
\hline FA3 & The relative with developmental disorder is physically autonomous \\
\hline FA4 & $\begin{array}{l}\text { The relative with developmental disorder has a good relationship with his/her classmates } \\
\text { Family Climate }\end{array}$ \\
\hline FC1 & All the members of my family trust each other enough to ask for help whenever they need it \\
\hline FC2 & All the members of my family show affection and love \\
\hline FC3 & My family adequately solves the conflicts that may arise among us \\
\hline FC4 & All the members of my family can pour out their hearts whenever they need to \\
\hline FC5 & $\begin{array}{l}\text { All the members of my family talk openly about our concerns } \\
\text { Emotional Stability }\end{array}$ \\
\hline ES1 & My family feels good when we see the relative with developmental disorder \\
\hline ES2 & My family is at peace, because we see that the relative with developmental disorder is progressing \\
\hline ES3 & $\begin{array}{l}\text { The relative with developmental disorder has material goods suitable for his/her age (games, daily use material, etc) } \\
\text { Economic Well-Being }\end{array}$ \\
\hline EW-B1 & My family can afford the needs of all its members \\
\hline EW-B2 & My family has enough resources to overcome critical and difficult moments \\
\hline EW-B3 & My family can afford the psychological and/or psychiatric attention of all its members \\
\hline EW-B4 & My family can afford some craving \\
\hline EW-B5 & $\begin{array}{l}\text { My family can cover the costs derived from the participation of the relative with developmental disorder in social } \\
\text { leisure activities }\end{array}$ \\
\hline \multirow[t]{2}{*}{ EW-B6 } & My family is in enough economic balance to face the future without worries \\
\hline & Satisfaction [39] \\
\hline SAT1 & I am satisfied with the service provided in this centre \\
\hline SAT2 & I am happy with that this centre offers me \\
\hline SAT3 & My decision to go to this centre was appropriate \\
\hline
\end{tabular}

\section{References}

1. Federación Estatal de Asociaciones de Profesionales de la Atención Temprana (GAT). White Paper on Early Intervention; Real Patronato Sobre Discapacidad, Ed.; Ministerio de Sanidad, Política Social e Igualdad: Madrid, Spain, 2005.

2. Robles-Bello, M.A.; Sánchez-Teruel, D. Atención infantil temprana en España. Pap. Del Psicólogo 2013, 34, 132-143.

3. Samuel, P.S.; Rillotta, F.; Brown, I. Review: The development of family quality of life concepts and measures. J. Intellect. Disabil. Res. 2012, 56, 1-16. [CrossRef]

4. Mas, J.M.; Dunst, C.J.; Balcells-Balcells, A.; Garcia-Ventura, S.; Giné, C.; Cañadas, M. Family-centered practices and the parental well-being of young children with disabilities and developmental delay. Res. Dev. Disabil. 2019, 94, 103495. [CrossRef]

5. Rosenbaum, P.; King, S.; Law, M.; King, G.; Evans, J. Family-centred service: A conceptual framework and research review. Phys. Occup. Ther. Pediatr. 1998, 18, 1-20. [CrossRef]

6. Morgan, C.; Novak, I.; Badawi, N. Enriched environments and motor outcomes in cerebral palsy: Systematic review and meta-analysis. Pediatrics 2013, 132, e735-e746. [CrossRef]

7. Löwing, K.; Bexelius, A.; Brogren Carlberg, E. Activity focused and goal directed therapy for children with cerebral palsy-Do goals make a difference? Disabil. Rehabil. 2009, 31, 1808-1816. [CrossRef] [PubMed]

8. Baker, T.; Haines, S.; Yost, J.; DiClaudio, S.; Braun, C.; Holt, S. The role of family-centered therapy when used with physical or occupational therapy in children with congenital or acquired disorders. Phys. Ther. Rev. 2012, 17, 29-36. [CrossRef]

9. Morgan, C.; Darrah, J.; Gordon, A.M.; Harbourne, R.; Spittle, A.; Johnson, R.; Fetters, L. Effectiveness of motor interventions in infants with cerebral palsy: A systematic review. Dev. Med. Child. Neurol. 2016, 58, 900-909. [CrossRef]

10. Ashcraft, L.E.; Asato, M.; Houtrow, A.J.; Kavalieratos, D.; Miller, E.; Ray, K.N. Parent Empowerment in Pediatric Healthcare Settings: A Systematic Review of Observational Studies. Patient 2019, 12, 199-212. [CrossRef]

11. Jones, S.; Bremer, E.; Lloyd, M. Autism spectrum disorder: Family quality of life while waiting for intervention services. Qual. Life Res. 2017, 26, 331-342. [CrossRef] 
12. Montes, A. The Early Child Care Centres: A net of centres and professionals. Pediatría Atención Primaria 2013, 15, 21-25.

13. Boletín Oficial de la Junta de Andalucía. Decreto 85/2016, de 26 de Abril, por el Que se Regula la Intervención Integral de la Atención Infantil Temprana en Andalucía; Junta de Andalucía: Sevilla, Spain, 2016.

14. García-Grau, P.; Martínez-Rico, G.; McWilliam, R.A.; Grau, D. Early Intervention and Family-Centeredness in Spain: Description and profile of professional practices. Top. Early Child. Spec. Educ. 2019, 41, 160-172. [CrossRef]

15. Kruijsen-Terpstra, A.J.A.; Ketelaar, M.; Boeije, H.; Jongmans, M.J.; Gorter, J.W.; Verheijden, J.; Lindeman, E.; Verschuren, O. Parents' experiences with physical and occupational therapy for their young child with cerebral palsy: A mixed studies review. Child Care Health Dev. 2014, 40, 787-796. [CrossRef]

16. Richardson, Z.S.; Scully, E.A.; Dooling-Litfin, J.K.; Murphy, N.J.; Rigau, B.; Khetani, M.A.; McManus, B.M. Early Intervention Service Intensity and Change in Children's Functional Capabilities. Arch. Phys. Med. Rehabil. 2020, 101, 815-821. [CrossRef] [PubMed]

17. Khetani, M.A.; McManus, B.M.; Albrecht, E.C.; Kaelin, V.C.; Dooling-Litfin, J.K.; Scully, E.A. Early intervention service intensity and young children's home participation. BMC Pediatr. 2020, 20,1-10. [CrossRef]

18. Kilbourne, W.E.; Duffy, J.A.; Duffy, M.; Giarchi, G. The applicability of SERVQUAL in cross-national measurements of health-care quality. J. Serv. Mark. 2004, 18, 524-533. [CrossRef]

19. Moliner Cantos, C.; Gracia Grau, E.; Lorente Prieto, L.; Martínez Tur, V. Structure and validation of a contextual quality of life scale for people with intellectual disabilities in social services: An organization-oriented measure from an external perspective. Perspect. Em Gestão Conhecimento 2013, 3, 80-94.

20. Hu, X.; Summers, J.A.; Turnbull, A.; Zuna, N. The quantitative measurement of family quality of life: A review of available instruments. J. Intellect. Disabil. Res. 2011, 55, 1098-1114. [CrossRef]

21. Tseng, M.H.; Chen, K.L.; Shieh, J.Y.; Lu, L.; Huang, C.Y.; Simeonsson, R.J. Child characteristics, caregiver characteristics, and environmental factors affecting the quality of life of caregivers of children with cerebral palsy. Disabil. Rehabil. 2016, 38, $2374-2382$. [CrossRef] [PubMed]

22. Pain, K.; Dunn, M.; Anderson, G.; Darrah, J.; Kratochvil, M. Quality of life: What does it mean in rehabilitation? J. Rehabil. 1998, 54,5 .

23. Cappe, E.; Wolff, M.; Bobet, R.; Adrien, J.L. Quality of life: A key variable to consider in the evaluation of adjustment in parents of children with autism spectrum disorders and in the development of relevant support and assistance programmes. Qual. Life Res. 2011, 20, 1279-1294. [CrossRef] [PubMed]

24. Zeng, S.; Hu, X.; Zhao, H.; Stone-MacDonald, A.K. Examining the relationships of parental stress, family support and family quality of life: A structural equation modeling approach. Res. Dev. Disabil. 2020, 96, 103523. [CrossRef] [PubMed]

25. Oliver, R.L. Whence consumer loyalty? J. Mark. 1999, 63, 33-44. [CrossRef]

26. Kelesidou, S.; Chatzikou, M.; Tsiamagka, E.; Koutra, E.; Abakoumkin, G.; Tseliou, E. The role of parents' educational level and centre type in parent satisfaction with early childhood care centres: A study in Greece. Eur. Early Child. Educ. Res. J. 2017, 25, 768-783. [CrossRef]

27. Chiu, S.J.; Lin, I.F.; Chou, Y.T.; Chien, L.Y. Family quality of life among Taiwanese children with developmental delay before and after early intervention. J. Intellect. Disabil. Res. 2020, 64, 589-601. [CrossRef]

28. Furrer, M.; Jakob, N.J.; Cattapan-Ludewing, K.; Seixas, A.; Huber, C.G.; Schneeberger, A.R. Patient Satisfaction and Quality of Life in People with Schizophrenia-Spectrum Disorders in a Rural Area. Adm. Policy Ment. Health Ment. Health Serv. Res. 2018, 45, 245-253. [CrossRef]

29. Lanfredi, M.; Candini, V.; Buizza, C.; Ferrari, C.; Boero, M.E.; Giobbio, G.M.; Goldschmidt, N.; Greppo, S.; Iozzino, L.; Maggi, P.; et al. The effect of service satisfaction and spiritual well-being on the quality of life of patients with schizophrenia. Psychiatry Res. 2014, 216, 185-191. [CrossRef]

30. Lu, T.; Tu, R.; Jen, W. The role of service value and switching barriers in an integrated model of behavioural intentions. Total Qual. Manag. Bus. Excell. 2011, 22, 1071-1089. [CrossRef]

31. García Fernández, J.; Bernal García, A.; Vélez Colón, L.; Pitts, B.G.; Gálvez Ruíz, P. Consumer behaviour and sport services: An examination of fitness centre loyalty. Int. J. Sport Manag. Mark. 2017, 18, 8. [CrossRef]

32. Yilmaz, V.; Ari, E. The effects of service quality, image, and customer satisfaction on customer complaints and loyalty in high-speed rail service in Turkey: A proposal of the structural equation model. Transp. A Transp. Sci. 2017, 13, 67-90. [CrossRef]

33. García-Grau, P.; Martínez-Rico, G.; McWilliam, R.A.; Cañadas Pérez, M. Typical and Ideal Practices in Early Intervention in Spain During a Transformation Process of Professional Practices. J. Early Interv. 2019, 42, 3-19. [CrossRef]

34. Romero-Galisteo, R.P.; Blanco-Villaseñor, Á.; Moreno-Morales, N.; Gálvez-Ruiz, P. Early intervention and perceived quality. Medicine 2019, 98, e15173. [CrossRef] [PubMed]

35. Giné, C.; Mas, J.M.; Balcells-Balcells, A.; Baqués, N.; Simón, C. Escala de Calidad de Vida Familiar Para Familias con hijos/as Menores de 18 Años con Discapacidad Intelectual y/o en el Desarrollo. Versión Revisada. CdVF-ER (<18); Plena Inclusión: Madrid, Spain, 2018.

36. Oliver, R.L. Satisfaction a Behavioral Perspective on the Consumer; The McGraw-Hill Companies, Inc.: New York, NY, USA, 1997.

37. Romero-Galisteo, R.P.; Gálvez Ruiz, P.; Blanco Villaseñor, A.; Rodríguez-Bailón, M.; González-Sánchez, M. What families really think about the quality of early intervention centers: A perspective from mixed methods. PeerJ 2020, 8, e10193. [CrossRef] [PubMed]

38. Anderson, J.C.; Gerbing, D.W. Structural Equation Modeling in Practice: A Review and Recommended Two-Step Approach. Psychol. Bull. 1988, 103, 411-423. [CrossRef] 
39. Hair, J.F.; Sarstedt, M.; Hopkins, L.; Kuppelwieser, V.G. Partial least squares structural equation modeling (PLS-SEM): An emerging tool in business research. Eur. Bus. Rev. 2014, 26, 106. [CrossRef]

40. Jöreskog, K.G.; Sörbom, D. Recent Developments in Structural Equation Modeling. J. Mark. Res. 1982, 19, 404-416. [CrossRef]

41. Hair, J.F.; Black, W.C.; Babin, B.J.; Anderson, R.E. Multivariate Data Analysis, 7th ed.; Pearson Prentice-Hall: New York, NY, USA, 2010.

42. Fornell, C.; Larcker, D.F. Evaluating Structural Equation Models with Unobservable Variables and Measurement Error. J. Mark. Res. 1981, 18, 39-50. [CrossRef]

43. Tabachnick, B.G.; Fidell, L.S. Using Multivariate Statistics, 6th ed.; Pearson Educational, Inc.: Upper Saddle River, NJ, USA, 2013.

44. Dormann, C.F.; Elith, J.; Bacher, S.; Buchmann, C.; Carl, G.; Carré, G.; Marquéz, J.R.G.; Gruber, B.; Lafourcade, B.; Leitão, P.J.; et al. Collinearity: A review of methods to deal with it and a simulation study evaluating their performance. Ecography 2013, 36, 27-46. [CrossRef]

45. Bentler, P.M. EQS 6 Structural Equations Program. Manual; University of California Press: Berkeley, CA, USA, 1989; ISBN 1885898037.

46. Kline, R.B. Principles and Practice of Structural Equation Modeling, 2nd ed.; The Guilford Press: New York, NY, USA, 2005; ISBN 9781462523351.

47. Worthington, R.L.; Whittaker, T.A. Scale Development Research. Couns. Psychol. 2006, 34, 806-838. [CrossRef]

48. Niels Blunch. Introduction to Structural Equation Modeling Using IBM SPSS Statistics and Amos; SAGE Publications Ltd.: Thousand Oaks, CA, USA, 2008.

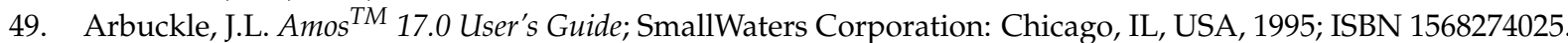

50. Maroco, J.; Garcia-Marques, T. Qual a Fiabilidade do alfa de Cronbach? Questões Antigas e soluções Modernas? Laboratório Psicol. 2006, 3, 65-90. [CrossRef]

51. Van Loon, J.; Claes, C.; Vandevelde, S.; Van Hove, G.; Schalock, R.L. Assessing individual support needs to enhance personal outcomes. Exceptionality 2010, 18, 193-202. [CrossRef]

52. Olaleye, O.A.; Hamzat, T.K.; Oloso, M.O. Perceived quality of physiotherapy services among informal caregivers of children with cerebral palsy in Ibadan, Nigeria. J. Pediatr. Rehabil. Med. 2015, 8, 227-234. [CrossRef] [PubMed]

53. Wang, Y.; Huang, Z.; Kong, F. Parenting stress and life satisfaction in mothers of children with cerebral palsy: The mediating effect of social support. J. Health Psychol. 2020, 25, 416-425. [CrossRef] [PubMed]

54. Bhopti, A.; Brown, T.; Lentin, P. Family Quality of Life. J. Early Interv. 2016, 38, 191-211. [CrossRef]

55. Ponte Mittelbrun, J.; Cardama Barrientos, J.; Arlazon Francés, J.L.; Belda Oriola, J.C.; González Franc, T.; Vived Cote, E. Guía de Estándares de Calidad en Atención Temprana; Ministerio de Trabajo y Asuntos Sociales: Madrid, Spain, 2004; ISBN 8484460738.

56. Konstantina, N.; Fotiadou, E.; Kontaxakis, E.; Giagazoglou, P.; Vasilis, T.; Sidiropoulou, M. Parental satisfaction with early intervention services for children with visual impairments and multiple disabilities in Greece. J. Phys. Educ. Sport 2014, 14, 60-65. [CrossRef]

57. Souza, A.C.; Alexandre, N.M.C.; Guirardello, E.B. Psychometric properties in PROMs evaluation of reliability and validity. Epidemiol. Serv. Saude 2017, 26, 649-659. [CrossRef]

58. Hu, H.H.; Kandampully, J.; Juwaheer, D.D. Relationships and impacts of service quality, perceived value, customer satisfaction, and image: An empirical study. Serv. Ind. J. 2009, 29, 111-125. [CrossRef]

59. Žabkar, V.; Brenčič, M.M.; Dmitrović, T. Modelling perceived quality, visitor satisfaction and behavioural intentions at the destination level. Tour. Manag. 2010, 31, 537-546. [CrossRef]

60. Almasri, N.A.; Palisano, R.J.; Dunst, C.J.; Chiarello, L.A.; O’Neil, M.E.; Polansky, M. Determinants of needs of families of children and youth with cerebral palsy. Child. Heal. Care 2011, 40, 130-154. [CrossRef]

61. Park, E.; Kim, J. Activity limitation in children with cerebral palsy and parenting stress, depression, and self-esteem: A structural equation model. Pediatr. Int. 2020, 62, 459-466. [CrossRef]

62. Colver, A.; Thyen, U.; Arnaud, C.; Beckung, E.; Fauconnier, J.; Marcelli, M.; McManus, V.; Michelsen, S.I.; Parkes, J.; Parkinson, K.; et al. Association between participation in life situations of children with cerebral palsy and their physical, social, and attitudinal environment: A cross-sectional multicenter European study. Arch. Phys. Med. Rehabil. 2012, 93, 2154-2164. [CrossRef] [PubMed]

63. Hsiao, Y.J.; Higgins, K.; Pierce, T.; Whitby, P.J.S.; Tandy, R.D. Parental stress, family quality of life, and family-teacher partnerships: Families of children with autism spectrum disorder. Res. Dev. Disabil. 2017, 70, 152-162. [CrossRef] [PubMed]

64. Verdam, M.G.E.; Oort, F.J.; Sprangers, M.A.G. Using structural equation modeling to investigate change and response shift in patient-reported outcomes: Practical considerations and recommendations. Qual. Life Res. 2021, 1, 3. [CrossRef] 